\title{
Research on AHP-based Entrepreneurial Oriented Evaluation Model \\ Taking Manufacturing Enterprises as an Example
}

\author{
Feiran Guo ${ }^{1}$ \\ ${ }^{1}$ Wuhan University of Technology Wuhan, China
}

\begin{abstract}
As the foundation of China's real economy, manufacturing industry is an important promoter of China's industrial transformation and upgrading. As market uncertainty increases, how to quickly respond to market changes and maintain a competitive advantage is a concern for manufacturing companies. Entrepreneurship orientation is an important strategy for enterprises to maintain vitality and sustain healthy development, which is of great significance to the development of manufacturing enterprises. This paper sorts out 21 specific factors in 5 categories that affect the entrepreneurial orientation of the manufacturing industry, and constructs an evaluation model of the entrepreneurial orientation of the manufacturing enterprises based on AHP, which provides directions for the transformation and upgrading of the manufacturing industry.
\end{abstract}

\section{INTRODUCTION}

Facing an international environment full of competition and challenges, it is imperative for China's manufacturing industry to strengthen the driving force for innovation and realize resource renewal. More research shows that the promotion effect of entrepreneurial orientation on organizational growth performance is more prominent in manufacturing companies. Therefore, the establishment of entrepreneurship-oriented evaluation model is of great significance to the transformation and upgrading of China's manufacturing enterprises. The academic research on entrepreneurial orientation is mainly divided into two aspects: the influence of entrepreneurial orientation and the relationship between entrepreneurial orientation and corporate performance. Miller (1983) divides entrepreneurial orientation into three dimensions: innovation, first mover and risk taking[1]. Covin and Slevin created a three-dimensional nine-term entrepreneurial vector table has been widely used in the research of later scholars[2]. However, most researchers regard entrepreneurial orientation as a holistic concept, but they ignore the special contribution of each dimension of entrepreneurial orientation to the growth performance of the enterprise; and for the measurement of entrepreneurial orientation, the cumulative scale is mostly used, which is difficult to ensure the accuracy of the measurement. In summary, this article takes manufacturing enterprises as an example to deeply study the impact of various dimensions of entrepreneurial orientation on its performance, build an entrepreneurial orientation evaluation model, and provide reference for policy formulation and enterprise transformation and upgrading.

\section{AHP-based evaluation model for entrepreneurial orientation of manufacturing enterprises}

\subsection{Entrepreneurship-oriented five-dimensional reflection model}

This model is based on the "Entrepreneurial Orientation Overall Strategy View" proposed by Covin and Slevin (1991), which regards entrepreneurial orientation as a high-level latent variable, which changes through changes in its key dimensions. The use of a five-dimensional reflection model is conducive to improving measurement confidence and making it easier to reveal the mechanism of entrepreneurial orientation on corporate growth performance.

Table1. Entrepreneurial orientation-enterprise growth

\begin{tabular}{|l|l|l|}
\multicolumn{2}{c}{ performance model } \\
\hline Latent variable & Independent variable & Dependent variable \\
\hline \multirow{3}{*}{$\begin{array}{l}\text { Entrepreneurial } \\
\text { rientation }\end{array}$} & Innovative & \multirow{3}{*}{ Growth performance } \\
\cline { 2 - 2 } & Proactive & \\
\cline { 2 - 2 } & Risk-taking & \\
\cline { 2 - 2 } & Competitive & \\
\cline { 2 - 2 } & Autonomy & \\
&
\end{tabular}

2.2 Construction of evaluation system for entrepreneurial orientation of manufacturing enterprises 
AHP is a decision method combining quantitative and qualitative analysis proposed by TLSatty, an operations research professor, in the 1970 s. It uses the 1-9 scale to objectively quantify the subjective evaluation of people, and obtains the weight through the comparison between the indicators, thereby ensuring the accuracy and objectivity of the model. This article decomposes the five dimensions of entrepreneurial orientation into 15 specific impact indicators by consulting a large number of relevant materials, interviewing relevant experts, and combining the characteristics of the manufacturing industry.

Table2. Evaluation system for entrepreneurial orientation of manufacturing enterprises

\begin{tabular}{|c|c|c|}
\hline Target layer & $\begin{array}{l}\text { Criterion } \\
\text { layer }\end{array}$ & Scheme layer \\
\hline \multirow{15}{*}{$\begin{array}{l}\text { Entrepreneurial } \\
\text { orientation A }\end{array}$} & \multirow{3}{*}{$\begin{array}{l}\text { Innovative } \\
\text { B1 }\end{array}$} & $\mathrm{R} \& \mathrm{D}$ input intensity $\mathrm{C} 1$ \\
\hline & & Number of patents $\mathrm{C} 2$ \\
\hline & & Proportion of R \& D personnel C3 \\
\hline & \multirow[t]{3}{*}{ Proactive B2 } & Policy grasping ability $\mathrm{C} 4$ \\
\hline & & Customer satisfaction C5 \\
\hline & & Market share C6 \\
\hline & \multirow[t]{3}{*}{$\begin{array}{l}\text { Risk-taking } \\
\text { B3 }\end{array}$} & Entrepreneurship C7 \\
\hline & & $\begin{array}{l}\text { High financial leverage risk } \\
\text { taking abilityC8 }\end{array}$ \\
\hline & & Management Incentive C9 \\
\hline & \multirow[t]{3}{*}{$\begin{array}{l}\text { Competitive } \\
\text { B4 }\end{array}$} & Market share $\mathrm{C} 10$ \\
\hline & & $\begin{array}{l}\text { Willingness to develop high } \\
\text { value-added productsC } 11\end{array}$ \\
\hline & & Mergers and Acquisitions C12 \\
\hline & \multirow[t]{3}{*}{$\begin{array}{l}\text { Autonomy } \\
\text { B5 }\end{array}$} & Organization flatness degree $\mathrm{C} 13$ \\
\hline & & $\begin{array}{l}\text { Incentive internal innovation } \\
\text { policy intensity } \mathrm{C} 14\end{array}$ \\
\hline & & $\begin{array}{l}\text { Whether employees hold shares } \\
\text { C15 }\end{array}$ \\
\hline
\end{tabular}

\subsection{Explanation of the Evaluation System of Entrepreneurial Orientation for Manufacturing Enterprises}

\subsubsection{Innovative:}

The demand for market innovation stimulates enterprises to generate innovation consciousness. Under the guidance of innovation consciousness, enterprises create new products and new services by changing innovation methods and increasing innovation investment, so as to meet market demand and obtain innovation profits. In the process of independent innovation of enterprises, innovation consciousness is usually reflected in the enterprise's innovation culture and entrepreneurs' willingness to innovate. Manufacturing companies will strengthen their innovation capabilities by increasing R \& $\mathrm{D}$ investment and introducing high-level scientific and technological talents. The number of invention patents, the success rate of R \& D conversion, and the market share of new products can measure the innovation output capacity of an enterprise[3].

\subsubsection{Proactive:}

Proactiveness means that the company has a forwardlooking strategic vision and is the first to introduce new products and technologies or enter new markets[4]. Proactive companies often focus on analyzing and predicting customer needs, tapping customers' pain points and itching points, and conducting demand-oriented innovation. On the other hand, by paying close attention to the frontiers of policy and technology, they can grasp the pulse of the times and accumulate scarce resources[5].Relevant research shows that market share is still an important indicator to measure the initiative of enterprises[6].

\subsubsection{Risk-taking:}

High-risk commitment means that the company is more inclined to high-risk and high-return business activities, and has a higher tolerance for investment failure. Based on the perspective of internal governance, entrepreneurs 'courageousness is an important influencing factor. For the entrusted agent, the agency problem can be alleviated through equity incentives, promotion incentives, and salary incentives to enhance the enterprise's ability to bear risks. The involvement in unknown fields often faces huge uncertainties, requiring companies to have good cash flow management capabilities, so a higher bank credit rating, a higher capital turnover rate and a reasonable asset-liability ratio will reflect the company 's higher Risk-taking capacity

\subsubsection{Competitive:}

In a dynamic and complex market environment, competition among enterprises is becoming increasingly fierce. Enterprises can seize market share through strategic layout such as cost leadership and differentiation, thereby gaining market initiative and high returns. Relevant research shows that companies with high competitive enthusiasm often adopt non-traditional "overwhelming" strategies, giving them an absolute market advantage.

\subsubsection{Autonomy:}

Within the company, the degree of expression of employees' ideas, the realization space of team goals, and whether the organization adopts flexible management are important measures of company autonomy. In the era of economic globalization and the interconnection of all things, a flat and flexible form of organizational management means the improvement of organizational resilience and flexibility, the improvement of the quality of management personnel and the multiplication of enterprise efficiency. 


\subsection{Construct the judgment matrix}

In this study, a questionnaire was distributed to 15 research experts, using a 1-9 scale scoring table. After multiple rounds of anonymous scoring and discussion, the expert scoring average was used to construct a judgment matrix.

Table3. Seaty1-9 scaling method

\begin{tabular}{|c|c|}
\hline Scaling & Meaning \\
\hline 1 & $\begin{array}{l}\text { It means that the two elements have the same } \\
\text { importance }\end{array}$ \\
\hline 3 & The former is slightly more important than the latter \\
\hline 5 & $\begin{array}{l}\text { The former is obviously more important than the } \\
\text { latter }\end{array}$ \\
\hline 7 & The former is strongly more important than the latter \\
\hline 9 & $\begin{array}{l}\text { The former is extremely more important than the } \\
\text { latter }\end{array}$ \\
\hline $2,4,6,8$ & $\begin{array}{l}\text { Represents the median value of the above adjacent } \\
\text { judgment }\end{array}$ \\
\hline
\end{tabular}

Table4. Criteria layer-target layer A judgment matrix

\begin{tabular}{|l|l|l|l|l|l|}
\hline A & B1 & B2 & B3 & B4 & B5 \\
\hline B1 & 1 & 7.9237 & 5.4820 & 8.5793 & 3.5889 \\
\hline B2 & 0.1262 & 1 & 3.1396 & 2.0547 & 3.5954 \\
\hline B3 & 0.1824 & 0.3185 & 1 & 1.0041 & 0.9436 \\
\hline B4 & 0.1166 & 0.4867 & 0.9960 & 1 & 1.9078 \\
\hline B5 & 0.2786 & 0.2781 & 1.0598 & 0.5242 & 1 \\
\hline
\end{tabular}

Table5. Scheme layer-criteria layer B2 judgment matrix

\begin{tabular}{|l|l|l|l|}
\hline B1 & C1 & C2 & C3 \\
\hline C1 & 1 & 5 & 0.3333 \\
\hline C2 & 0.2 & 1 & 0.1429 \\
\hline C3 & 3 & 7 & 1 \\
\hline
\end{tabular}

Table6. Scheme layer-criteria layer B2 judgment matrix

\begin{tabular}{|l|l|l|l|}
\hline B2 & C4 & C5 & C6 \\
\hline C4 & 1 & 3.0138 & 3.9898 \\
\hline C5 & 0.3318 & 1 & 0.5153 \\
\hline C6 & 0.2506 & 1.9405 & 1 \\
\hline
\end{tabular}

Table7. Scheme layer-criteria layer B3 judgment matrix

\begin{tabular}{|l|l|l|l|}
\hline B3 & C7 & C8 & C9 \\
\hline C7 & 1 & 6.0323 & 8.5780 \\
\hline C8 & 0.1658 & 1 & 3.5694 \\
\hline C9 & 0.1166 & 0.2802 & 1 \\
\hline
\end{tabular}

Table8. Scheme layer-criteria layer B4 judgment matrix

\begin{tabular}{|l|l|l|l|}
\hline B4 & C10 & C11 & C12 \\
\hline C10 & 1 & 3.7304 & 6.200 \\
\hline C11 & 0.2681 & 1 & 4.3404 \\
\hline
\end{tabular}

\begin{tabular}{|l|l|l|l|}
\hline C12 & 0.1613 & 0.2304 & 1 \\
\hline \multicolumn{1}{|c|}{ Table9. } & \multicolumn{2}{|c|}{ Scheme layer-criteria layer B5 judgment matrix } \\
\hline B5 & C13 & C14 & C15 \\
\hline C13 & 1 & 4.7890 & 8.7700 \\
\hline C14 & 0.2088 & 1 & 4.6352 \\
\hline C15 & 0.1140 & 0.2157 & 1 \\
\hline
\end{tabular}

\subsection{Hierarchical total ordering and consistency check}

The weight vectors of the target layers B1, B2, B3, B4 and B5 are: $\mathrm{W}^{\mathrm{T}}=(\mathrm{w} 1, \mathrm{w} 2, \mathrm{w} 3, \mathrm{w} 4, \mathrm{w} 5)=(0.5529,0.1694$, $0.0837,0.1136,0.0840)$. This study calculates the total ranking results of the hierarchy and performs a consistency check: $\mathrm{CR}=\frac{\mathrm{CI}}{\mathrm{RI}} \approx 0.05379<0.1$, sample data passed consistency test.

Available evaluation index weights are shown in Table 10.

Table10. Weight of evaluation indicators for entrepreneurial orientation of manufacturing companies

\begin{tabular}{|c|c|c|c|c|}
\hline $\begin{array}{l}\text { First-level } \\
\text { indicators }\end{array}$ & Weights & $\begin{array}{l}\text { Secondary } \\
\text { indicators }\end{array}$ & $\begin{array}{l}\text { Global } \\
\text { weight }\end{array}$ & $\begin{array}{l}\text { Local } \\
\text { weight }\end{array}$ \\
\hline \multirow{3}{*}{$\begin{array}{c}\text { Innovative } \\
\text { B1 }\end{array}$} & \multirow[t]{3}{*}{0.5650} & $\mathrm{C} 1$ & 0.1598 & 0.2828 \\
\hline & & $\mathrm{C} 2$ & 0.0417 & 0.0738 \\
\hline & & C3 & 0.3635 & 0.6434 \\
\hline \multirow{3}{*}{ Proactive B2 } & \multirow[t]{3}{*}{0.1850} & $\mathrm{C} 4$ & 0.1148 & 0.6209 \\
\hline & & $\mathrm{C} 5$ & 0.0291 & 0.1571 \\
\hline & & C6 & 0.0411 & 0.2220 \\
\hline \multirow{3}{*}{$\begin{array}{c}\text { Risk-taking } \\
\text { B3 }\end{array}$} & \multirow[t]{3}{*}{0.0773} & C7 & 0.0581 & 0.7524 \\
\hline & & $\mathrm{C} 8$ & 0.0138 & 0.1792 \\
\hline & & C9 & 0.0053 & 0.0684 \\
\hline \multirow{3}{*}{$\begin{array}{c}\text { Competitive } \\
\text { B4 }\end{array}$} & \multirow[t]{3}{*}{0.0902} & C10 & 0.0598 & 0.6629 \\
\hline & & $\mathrm{C} 11$ & 0.0230 & 0.2551 \\
\hline & & C12 & 0.0074 & 0.0820 \\
\hline \multirow{3}{*}{$\begin{array}{c}\text { Autonomy } \\
\text { B5 }\end{array}$} & \multirow[t]{3}{*}{0.0825} & C13 & 0.0595 & 0.7208 \\
\hline & & C14 & 0.0178 & 0.2154 \\
\hline & & C15 & 0.0053 & 0.0638 \\
\hline
\end{tabular}

\section{Results and analysis}

According to Table 9, the weights of the various dimensions of manufacturing enterprise entrepreneurship orientation on growth performance are innovation $(0.5650)$ (denoting the weight, the same below), roactive, $(0.1850)$ competitive (0.0902), autonomy $(0.0825)$, risk-taking (0.0773).

With the integration of a new generation of information technology and manufacturing, technological innovation has become the core driving force for the upgrading of the manufacturing industry, a major technological breakthrough will improve quality and efficiency and expand profitability. Successful 
technological innovation comes from solving social needs. Highly proactive companies often focus on analyzing and predicting customer needs, conducting demand-oriented innovation, and accumulating scarce resources on the basis of grasping policies. In a dynamic and complex market environment, the competition between enterprises is becoming increasingly fierce, responding positively to market competition, and seizing market share through strategic layout such as cost leadership and differentiation to obtain market initiative and high returns. Focus on the first three dimensions will help manufacturing companies achieve higher growth performance.

\section{Conclusions and recommendations}

\subsection{The government}

First, the government should improve the intellectual property protection system, promote the transformation of achievements, and improve the independent innovation capabilities of enterprises; second, the government should strengthen the construction of a collaborative innovation system, promote the integration of production, education and research, and promote the optimization and integration of innovation resources; third, the government has increased fiscal and taxation support to release the company's endogenous innovation drive.

\subsection{The Enterprise}

First, manufacturing companies should increase R \& D funding, especially in basic innovation, they must introduce high-level innovative talents and master cuttingedge technological resources; second, companies should pay attention to the policies and market demand to seize market share; third, enterprises should pay attention to industry cooperation, promote the in-depth integration of manufacturing and information industries, and promote industry transformation and upgrading.

\section{References}

1. Danny Miller. The Correlates of Entrepreneurship in Three Types of Firms[J]. Management Science, 1983,29(7).

2. Covin J, Slevin D.Strategic management of small firms in hostile and benign environments[J].Strategic management journal,1989,(10):75-87.

3. Wangbin $\mathrm{Hu}$,Yuli Zhang. New enterprise entrepreneurial orientation translates into performance of new enterprise capabilities: theoretical models and empirical research in China [J] Nankai Management Review. 2011 (14).

4. Abdullah Ibrahim Al-Darmaki. The Effect of Total Quality Management, Organizational Excellence on Organizational Performance-The Moderating Role of Entrepreneurial Orientation. 2018, 10(2):130-144.

5. Yu Xing,Danhui Zheng. Entrepreneurial orientation's influence mechanism on enterprise growth: a structural view[J]. Southern Economy, 2014,(02):7488.

6. Hongjun Cao,Xiang Zheng. Research on Evaluation System of Enterprise Independent Innovation Ability[J]. China Industrial Economy, 2009(09):105114. 